\title{
Rapid Colorimetric Detection of Cartap Residues by AgNP Sensor with Magnetic Molecularly Imprinted Microspheres as Recognition Elements
}

\author{
Mao Wu ${ }^{1}$, Huiyun Deng ${ }^{1}$, Yajun Fan ${ }^{1}$, Yunchu Hu ${ }^{1}$, Yaping Guo ${ }^{1, *}$ and Lianwu Xie ${ }^{1,2, *(\mathbb{D})}$ \\ 1 College of Sciences, Central South University of Forestry and Technology, Changsha 410004, China; \\ wumaoweiming@126.com (M.W.); denghuiyuncsuft@126.com (H.D.); fanyajuncsfu@126.com (Y.F.); \\ huyunchu@csuft.edu.cn (Y.H.) \\ 2 College of Chemistry and Chemical Engineering, Central South University, Changsha 410083, China \\ * Correspondence: guoyaping@csuft.edu.cn (Y.G.); xielianwu@csuft.edu.cn (L.X.); \\ Tel.: +86-7318-5623-648 (L.X.)
}

Received: 28 May 2018; Accepted: 12 June 2018; Published: 14 June 2018

\begin{abstract}
The overuse of cartap in tea tree leads to hazardous residues threatening human health. A colorimetric determination was established to detect cartap residues in tea beverages by silver nanoparticles (AgNP) sensor with magnetic molecularly imprinted polymeric microspheres $\left(\mathrm{Fe}_{3} \mathrm{O}_{4} @ \mathrm{mSiO}_{2} @ \mathrm{MIPs}\right)$ as recognition elements. Using $\mathrm{Fe}_{3} \mathrm{O}_{4}$ as supporting core, mesoporous $\mathrm{SiO}_{2}$ as intermediate shell, methylacrylic acid as functional monomer, and cartap as template, $\mathrm{Fe}_{3} \mathrm{O}_{4} @ \mathrm{mSiO}_{2} @ \mathrm{MIPs}$ were prepared to selectively and magnetically separate cartap from tea solution before colorimetric determination by AgNP sensors. The core-shell $\mathrm{Fe}_{3} \mathrm{O}_{4} @ \mathrm{mSiO}_{2} @ \mathrm{MIPs}$ were also characterized by FT-IR, TEM, VSM, and experimental adsorption. The $\mathrm{Fe}_{3} \mathrm{O}_{4} @ \mathrm{mSiO}_{2} @ \mathrm{MIPs}$ could be rapidly separated by an external magnet in $10 \mathrm{~s}$ with good reusability (maintained $95.2 \%$ through 10 cycles). The adsorption process of cartap on $\mathrm{Fe}_{3} \mathrm{O}_{4} @ \mathrm{mSiO}_{2} @ \mathrm{MIPs}$ conformed to Langmuir adsorption isotherm with maximum adsorption capacity at $0.257 \mathrm{mmol} / \mathrm{g}$ and short equilibrium time of $30 \mathrm{~min}$ at $298 \mathrm{~K}$. The AgNP colorimetric method semi-quantified cartap $\geq 5 \mathrm{mg} / \mathrm{L}$ by naked eye and quantified cartap $0.1-5 \mathrm{mg} / \mathrm{L}$ with LOD $0.01 \mathrm{mg} / \mathrm{L}$ by UV-vis spectroscopy. The AgNP colorimetric detection after pretreatment with $\mathrm{Fe}_{3} \mathrm{O}_{4} @ \mathrm{mSiO}_{2} @ \mathrm{MIPs}$ could be successfully utilized to recognize and detect cartap residues in tea beverages.
\end{abstract}

Keywords: cartap residue; colorimetric determination; tea beverage; molecularly imprinted microsphere; selective recognition; silver nanoparticle sensor

\section{Introduction}

Cartap, an analogue of the natural insecticide nereistoxin, has been widely used to kill destructive pests in rice, vegetables, fruit trees and tea trees all over the world [1,2]. In spite of its low mammalian toxicity, the overuse of cartap could lead to hazardous residues threatening human health [3]. Hence, maximum residue limits for cartap have been ascertained by the food administrations of many nations including China. For example, the Ministry of Agriculture of China had set the maximum residue limit of cartap at $20 \mathrm{mg} / \mathrm{kg}$ for tea [4].

Aiming to reduce the risk of polluting the environment and to establish a safety standard of cartap, determining cartap content in food is of great importance. Various analytical methods have been used for detecting cartap, such as spectrophotometry [3,5,6], thin-layer chromatography [7], gas chromatography [8], high-performance liquid chromatography $[9,10]$, gas chromatography-mass spectrometry [11-13], liquid chromatography-tandem mass spectrometry [14]. These methods are 
successfully applied to qualitatively and quantitatively determine cartap. However, most of operation procedures of the above analytical methods are not only laborious and time-consuming, but also require expensive instruments and many organic solvents. In addition, in some cases, cartap must be transformed into nereistoxin compounds under alkaline conditions before detection [15]. Thus, novel, low-cost, rapid, concise, and accurate analytical methods such as colorimetric analysis are still in significant demand.

Silver nanoparticles (AgNP)-based colorimetric analysis had been paid more attention in recent years. AgNPs present intense colors which will produce characteristic absorption peaks due to the effect of surface plasmon resonance (SPR) [16]. The SPR effect derives from the size and shape of particles, inter-particle distances, and the dielectric properties of surroundings [17] which are related to the aggregation of nanoparticles. Extra substances added into the AgNP system can cause the inter-particle distance to change and subsequently result in quantifiable shifts of the UV-vis absorption, which is the fundamental principle of the colorimetric sensor [18]. Owing to the rapid, sensitive, and easy-to-use characteristics, AgNP colorimetric detection methods have been widely investigated to identify many chemical and biological molecules [19-22]. Nevertheless, the poor selectivity of those colorimetric methods has restricted its application in complicated sample matrices (e.g., foods) because copious interferents may also lead to AgNP aggregation. Because of that, numerous measures were taken to improve the selectivity of AgNP colorimetric sensors. For instance, Yuan et al. used amine-terminated generation 5 poly (amidoamine) dendrimers-stabilized AgNPs to calorimetrically detect mercury ions in aqueous solution [23]. Patel et al. developed a colorimetric method for the sensitive and selective detection of carbendazim fungicide in water and food samples using 4-aminobenzenethiol functionalized AgNPs as a colorimetric sensor [24]. However, synthesizing these AgNPs is complex and the sensitivity may be influenced by the stabilizers due to their prohibiting effects on the aggregation of AgNPs. Therefore, separation and enrichment of analyte from sample matrices need to be carried out properly before the analysis.

Generally, sample pretreatments using liquid-liquid extraction, precipitation, and centrifugation are largely employed before applying the above-mentioned colorimetric sensing techniques. For example, Liu et al. reported a visible spectrophotometry for the rapid assay of cartap with citrate-coated Au nanoparticles after the sample was pretreated by multiple liquid-liquid extractions, and cartap could be detected in the range of $0.05-0.6 \mathrm{mg} / \mathrm{kg}$ [3]. However, the pretreatments lack the selectivity and cannot completely remove the interferents. Other methods such as antibody-based [25] and aptamer-based [26] separation methods have been successfully established to separate and enrich pesticide residues from complex foodstuffs. However, high cost and laborious manufacture of antibody and aptamer critically restrict their application in conventional detection of pesticide residues in foods.

Lately, molecularly imprinted polymers (MIPs)-based pretreatment methods have been developed to successfully enrich some metabolites in vivo [27], food addictive Sudan [28], triazine herbicides [29], chlorpyrifos [18], trichlorfon [30], and organophosphorus pesticide residues [31] in diverse food products. In particular, core-shell magnetic MIPs with magnetic $\mathrm{Fe}_{3} \mathrm{O}_{4}$ as support $\left(\mathrm{Fe}_{3} \mathrm{O}_{4} @ \mathrm{mSiO}_{2} @ \mathrm{MIPs}\right)$ have been considered as desirable and have received increasing attention [32,33] owing to some notable advantages of unique magnetic properties for easily and rapidly recognizing and separating analytes from the matrix by external magnets after adsorption without a column-packing procedure [34-38]. Up to now, there has been no report involving the preparation of $\mathrm{Fe}_{3} \mathrm{O}_{4} @ \mathrm{mSiO}_{2} @ \mathrm{MIPs}$ with cartap as a template to efficaciously and selectively isolate and enrich cartap from complicated matrices.

The current research is conducted to develop a pretreatment with $\mathrm{Fe}_{3} \mathrm{O}_{4} @ \mathrm{mSiO}_{2} @ \mathrm{MIPs}$ as recognition elements before AgNP sensor colorimetric determination of cartap in tea beverages. $\mathrm{Fe}_{3} \mathrm{O}_{4} @ \mathrm{mSiO}_{2} @ \mathrm{MIPs}$ are prepared to specifically recognize cartap from mixture solution containing cartap and its four analogues including nereistoxin, bensultap, bisultap and monosultap (Figure 1). The AgNP colorimetric methods are exploited to high-throughput screen and semi-quantify cartap in tea beverages. As far as we know, there is no study that uses AgNP colorimetric detection with magnetic 
surface molecularly imprinted polymeric microspheres as recognition elements for high-throughput screening and semi-quantification of cartap in agri-food products.

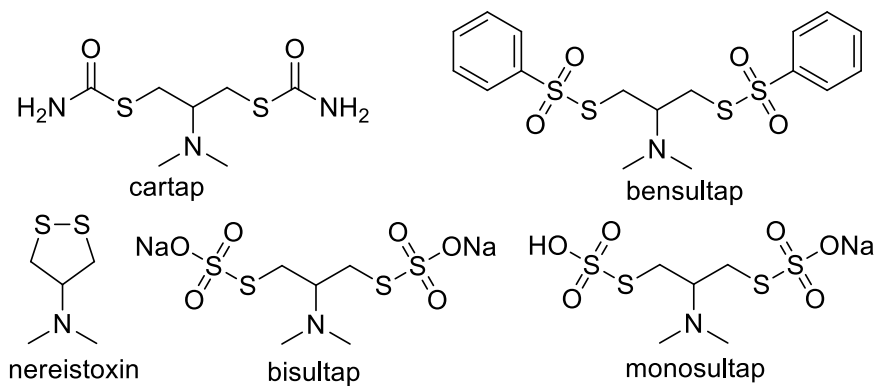

Figure 1. Chemical structures of cartap and its analogues.

\section{Results and Discussion}

\subsection{Preparation of $\mathrm{Fe}_{3} \mathrm{O}_{4} @ m \mathrm{SiO}_{2} @ M I P s$}

The preparation process of $\mathrm{Fe}_{3} \mathrm{O}_{4} @ \mathrm{mSiO}_{2} @ \mathrm{MIPs}$ is schematically shown in Figure 2. First, a solvothermal reaction was used to synthesize $\mathrm{Fe}_{3} \mathrm{O}_{4}$ microspheres which have higher magnetic response than those prepared by coprecipitation method. Then, a layer of cetyltrimethyl ammonium bromide $(\mathrm{CTAB}) / \mathrm{SiO}_{2}$ composites was coated over the $\mathrm{Fe}_{3} \mathrm{O}_{4}$ microspheres through a concise one-step sol-gel process using $\mathrm{CTAB}$ as a template for forming mesoporous structure. After removing CTAB in a mild way by acetone soxhlet extraction, well-dispersed $\mathrm{Fe}_{3} \mathrm{O}_{4} @ \mathrm{mSiO}_{2}$ particles with magnetic core and mesoporous silica shell were obtained [36]. By virtue of a higher ratio of surface to volume, mesoporous materials have remarkable advantages for preparing surface MIPs. IN particular, the mesoporous structure of silica shell could provide more surface area to graft various functional groups, which was beneficial to the adsorption of target molecules [39]. Besides, coating $\mathrm{SiO}_{2}$ over $\mathrm{Fe}_{3} \mathrm{O}_{4}$ would improve their dispersion in water, decrease agglomerations during reduplicated magnetic separation, and raise their reusability [40]. After that, in the presence of 2,2'-azobis(isobutyronitrile) (AIBN), vinyl groups were led into the surface of $\mathrm{Fe}_{3} \mathrm{O}_{4} @ \mathrm{mSiO}_{2}$ with MPS for reaction with ethylene glycol dimethacrylate (EGDMA) to initiate the copolymerization with preassembly solution of methylacrylic acid (MAA) and cartap, which interacted mainly on the hydrogen bond. Ultimately, the surface binding sites of $\mathrm{Fe}_{3} \mathrm{O}_{4} @ \mathrm{mSiO}_{2} @ \mathrm{MIPs}$ were realized by removing the templates. Thus, a filmy layer of MIPs was synthesized on the surface of solid support with micro size, which was beneficial for improving the mass transfer rate and completely removing the template [41].

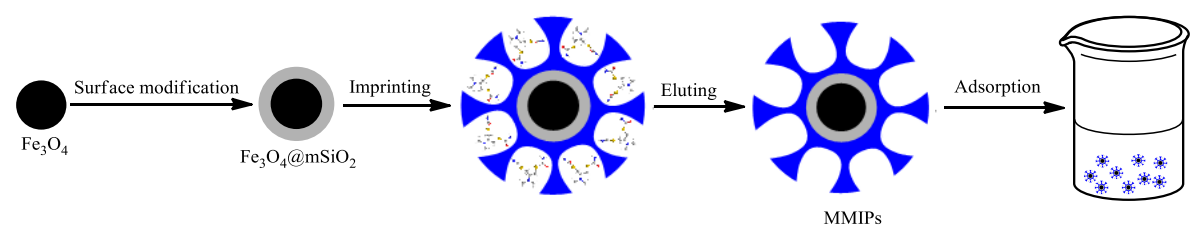

Figure 2. Schematics for the synthesis of $\mathrm{Fe}_{3} \mathrm{O}_{4} @ \mathrm{mSiO}_{2} @ \mathrm{MIPs}$.

\subsection{Characterization of $\mathrm{Fe}_{3} \mathrm{O}_{4} @ m \mathrm{miO}_{2} @ \mathrm{MIPs}$}

Morphology and particle size of prepared $\mathrm{Fe}_{3} \mathrm{O}_{4}$ nanoparticles, $\mathrm{Fe}_{3} \mathrm{O}_{4} @ \mathrm{mSiO}_{2}$ and $\mathrm{Fe}_{3} \mathrm{O}_{4} @ \mathrm{mSiO}_{2} @ \mathrm{MIPs}$ can be observed by TEM (Figure 3). About 20 nm thick $\mathrm{mSiO}_{2}$ shell (Figure 3b) was uniformly coated onto $\mathrm{Fe}_{3} \mathrm{O}_{4}$ dark core with about $200 \mathrm{~nm}$ diameter (Figure 3a). After the process of surface imprinting polymerization, an external polymer layer with $50 \mathrm{~nm}$ diameter was distinctly found to be around $\mathrm{Fe}_{3} \mathrm{O}_{4} @ \mathrm{mSiO}_{2}$ nanoparticles (Figure 3c), which indicated that the surface of $\mathrm{Fe}_{3} \mathrm{O}_{4} @ \mathrm{mSiO}_{2}$ nanoparticles had been successfully grafted by the MIPs layer. Thus, the 
core-shell structural $\mathrm{Fe}_{3} \mathrm{O}_{4} @ \mathrm{mSiO}_{2} @ \mathrm{MIPs}$ with diameter of about 250 nm were successfully synthesized with regular spherical shape and relatively narrow size distribution (Figure $3 c$ ). As the cylindrical mesoporous in $\mathrm{mSiO}_{2}$ layer were perpendicular to the $\mathrm{Fe}_{3} \mathrm{O}_{4}$ surface (Figure $3 \mathrm{~b}$ ), the imprinting precursor penetrated into the channels and the MIPs layer could be riveted into the internal surface of $\mathrm{Fe}_{3} \mathrm{O}_{4} @ \mathrm{mSiO}_{2}$ [42], which was favorable to more recognition sites and more strong capacity of adsorption.

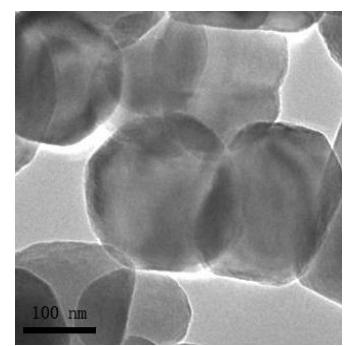

(a)

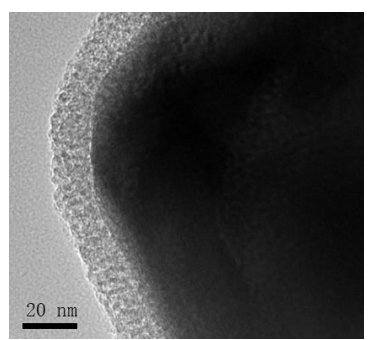

(b)

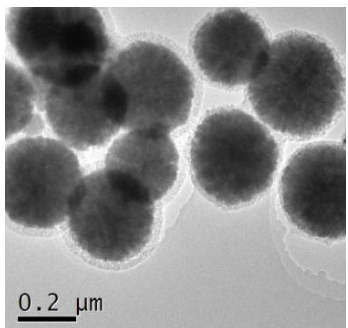

(c)

Figure 3. TEM images of (a) $\mathrm{Fe}_{3} \mathrm{O}_{4} ;$ (b) $\mathrm{Fe}_{3} \mathrm{O}_{4} @ \mathrm{mSiO}_{2}$; and (c) $\mathrm{Fe}_{3} \mathrm{O}_{4} @ \mathrm{mSiO}_{2} @ \mathrm{MIPs}$.

In FT-IR spectra, the strong Fe-O vibration absorption peak at $580 \mathrm{~cm}^{-1}$ (Figure S1a), the Si-O symmetric stretching vibration peak at $800 \mathrm{~cm}^{-1}$, and strong Si-O-Si asymmetric stretching vibration peak at $1072 \mathrm{~cm}^{-1}$ (Figure $\mathrm{S} 1 \mathrm{~b}$ ) indicated that $\mathrm{SiO}_{2}$ layer was successfully encapsulated on the surface of $\mathrm{Fe}_{3} \mathrm{O}_{4}$ nanoparticles. The characteristic absorption peaks at $2922 \mathrm{~cm}^{-1}$ and $2851 \mathrm{~cm}^{-1}(\mathrm{C}-\mathrm{H}$ stretching vibration) were ascribed to CTAB (Figure S1b). On the contrary, the inexistence of above C-H stretching vibration peaks in Figure S1c suggested the complete removal of CTAB. Moreover, the stretching vibration peak of the $C=C$ bonds at $1632 \mathrm{~cm}^{-1}$ was ascribed to the successful modification with vinyl groups (Figure S1c). The adsorption peak of $\mathrm{C}=\mathrm{O}$ stretching band at $1720 \mathrm{~cm}^{-1}$ (Figure S1d) for EDGMA indicated that the MIPs was successfully coated over the surface of $\mathrm{Fe}_{3} \mathrm{O}_{4} @ \mathrm{mSiO}_{2}$.

The magnetization curves of $\mathrm{Fe}_{3} \mathrm{O}_{4}$ nanoparticles, $\mathrm{Fe}_{3} \mathrm{O}_{4} @ \mathrm{mSiO}_{2}$ and $\mathrm{Fe}_{3} \mathrm{O}_{4} @ \mathrm{mSiO} \mathrm{O}_{2} @ \mathrm{MIPs}$ are shown in Figure 4. The shape of the three curves is similar, there is no residual magnetism, and the value of coercive force is zero, which shows that three types of materials are superparamagnetic. The magnetic saturation of resultant $\mathrm{Fe}_{3} \mathrm{O}_{4} @ \mathrm{mSiO}_{2} @ \mathrm{MIPs}$ was approximately $66 \mathrm{emu} / \mathrm{g}$ (Figure 4c), which was lower than those of $\mathrm{Fe}_{3} \mathrm{O}_{4}$ nanoparticles $(75 \mathrm{emu} / \mathrm{g})$ and $\mathrm{Fe}_{3} \mathrm{O}_{4} @ \mathrm{mSiO}_{2}(68 \mathrm{emu} / \mathrm{g})($ Figure 4a,b), which could be relevant to the magnetic inactive layer including $\mathrm{mSiO}_{2}$ and imprinted polymer layers. Nevertheless, the reduction of magnetism did not severely influence the magnetic separation of $\mathrm{Fe}_{3} \mathrm{O}_{4} @ \mathrm{mSiO}_{2} @ \mathrm{MIPs}$, and they kept intensely magnetic and could be collected within $10 \mathrm{~s}$ in solution by an external magnet (Figure $4 \mathrm{~d}$ ) and scattered rapidly after a gentle shake once the magnetic field was withdrawn.

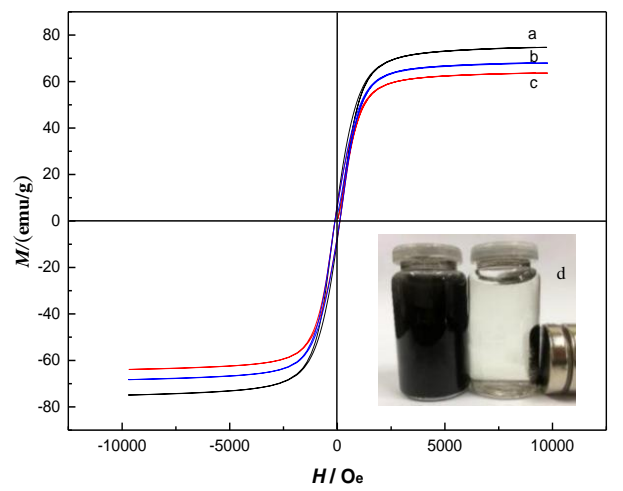

Figure 4. The magnetization curves of (a) $\mathrm{Fe}_{3} \mathrm{O}_{4} ;$ (b) $\mathrm{Fe}_{3} \mathrm{O}_{4} @ \mathrm{mSiO}_{2} ;$ (c) $\mathrm{Fe}_{3} \mathrm{O}_{4} @ \mathrm{mSiO}_{2} @ \mathrm{MIPs}$; and (d) the magnetic separation of $\mathrm{Fe}_{3} \mathrm{O}_{4} @ \mathrm{mSiO}_{2} @ \mathrm{MIPs}$ under the external magnet. 


\subsection{Adsorption Characteristics}

Adsorption isotherms of cartap on $\mathrm{Fe}_{3} \mathrm{O}_{4} @ \mathrm{mSiO}_{2} @ \mathrm{MIPs}$ and magnetic molecularly imprinted microspheres in the absences of template $\left(\mathrm{Fe}_{3} \mathrm{O}_{4} @ \mathrm{mSiO}_{2} @ \mathrm{NIPs}\right)$ were determined at $298 \mathrm{~K}, 308 \mathrm{~K}$ and $318 \mathrm{~K}$, respectively (Figure S2). The equilibrium adsorption capacity of cartap on $\mathrm{Fe}_{3} \mathrm{O}_{4} @ \mathrm{mSiO}_{2} @ \mathrm{MIPs}$ and $\mathrm{Fe}_{3} \mathrm{O}_{4} @ \mathrm{mSiO}_{2} @ \mathrm{NIPs}$ raised rapidly first, then lightly along with raising initial concentrations, and then approached saturation when the initial concentration reached $15.0 \mathrm{mmol} / \mathrm{L}$. The equilibrium adsorption capacity of cartap on $\mathrm{Fe}_{3} \mathrm{O}_{4} @ \mathrm{mSiO}_{2} @ \mathrm{MIPs}$ at $298 \mathrm{~K}$ was $0.257 \mathrm{mmol} / \mathrm{g}$, 9.5 times of that on $\mathrm{Fe}_{3} \mathrm{O}_{4} @ \mathrm{mSiO}_{2} @ \mathrm{NIPs}(0.027 \mathrm{mmol} / \mathrm{g})$, which could be caused by the imprinting effect. Hence, $\mathrm{Fe}_{3} \mathrm{O}_{4} @ \mathrm{mSiO}_{2} @ \mathrm{MIPs}$ showed higher adsorption capacity to cartap and might be suitable for isolating cartap from complex samples.

In addition, the equilibrium adsorption capacity of cartap on two sorbents increased along with the increase of temperature, which is consistent with previous research results that MIPs synthesized at higher temperatures tend to work better owing to the similar 3D structures at similarly higher temperatures. Furthermore, at higher temperatures the solvent possesses a lower viscosity and surface tension and meanwhile can improve the wetting of the $\mathrm{Fe}_{3} \mathrm{O}_{4} @ \mathrm{mSiO}_{2} @ \mathrm{MIPs}$, which then result in higher binding capacity to some extent. To estimate the binding performances of $\mathrm{Fe}_{3} \mathrm{O}_{4} @ \mathrm{mSiO}_{2} @ \mathrm{MIPs}$ or $\mathrm{Fe}_{3} \mathrm{O}_{4} @ \mathrm{mSiO}_{2} @ \mathrm{NIPs}$ further, two representatively isothermal models, namely the Langmuir Equation (1) and Freundlich Equation (2), were applied to fit the experimental data.

$$
\begin{aligned}
& \text { Langmuir equation : } \frac{1}{Q_{\mathrm{e}}}=\frac{1}{Q_{\mathrm{m}} K_{\mathrm{L}} c_{\mathrm{e}}}+\frac{1}{Q_{\mathrm{m}}} \\
& \text { Freundlich equation : } \ln Q_{\mathrm{e}}=\frac{1}{n} \ln c_{\mathrm{e}}+\ln K_{\mathrm{F}}
\end{aligned}
$$

where $Q_{\mathrm{e}}$ and $Q_{\mathrm{m}}$ are the equilibrium adsorption capacity (mmol/g) and the maximum adsorption capacity $(\mathrm{mmol} / \mathrm{g})$ respectively, $c_{\mathrm{e}}(\mathrm{mmol} / \mathrm{L})$ is the equilibrium concentration of cartap, $K_{\mathrm{L}}$ is a characteristic constant $(\mathrm{L} / \mathrm{mmol}), n$ and $K_{\mathrm{F}}$ are Freundlich constants.

The Langmuir equation can be used for characterizing a monolayer adsorption, and the Freundlich equation can be used for characterizing a multilayer adsorption and a monolayer adsorption. Supplementary material Table S1 summarizes the fitted parameters $Q_{\mathrm{m}}, K_{\mathrm{L}}, K_{\mathrm{F}}, n$ and $\mathrm{R}^{2}$ (correlation coefficient), which indicates that the Langmuir equation with $\mathrm{R}^{2}>0.99$ might be better fit the isotherm experimental data. In addition, $Q_{\mathrm{m}}$ (cal) calculated by the Langmuir equation was closer to $Q_{\mathrm{m}}(\exp )$ measured in the experiment. Therefore, the adsorption process of cartap could be regarded as a monolayer adsorption. Moreover, the $Q_{\mathrm{m}}(\mathrm{exp})$ of $\mathrm{Fe}_{3} \mathrm{O}_{4} @ \mathrm{mSiO}_{2} @ \mathrm{MIPs}_{\mathrm{S}}$ of cartap at diverse temperatures were enormously higher than those of $\mathrm{Fe}_{3} \mathrm{O}_{4} @ \mathrm{mSiO}_{2} @ \mathrm{NIPs}$, which demonstrated that $\mathrm{Fe}_{3} \mathrm{O}_{4} @ \mathrm{mSiO}_{2} @ \mathrm{MIPs}$ exhibited higher binding affinity for cartap than $\mathrm{Fe}_{3} \mathrm{O}_{4} @ \mathrm{mSiO}_{2} @ \mathrm{NIPs}$.

Adsorption kinetic curves of adsorption of cartap on $\mathrm{Fe}_{3} \mathrm{O}_{4} @ \mathrm{mSiO}_{2} @ \mathrm{MIPs}$ and $\mathrm{Fe}_{3} \mathrm{O}_{4} @ \mathrm{mSiO}_{2} @ \mathrm{NIPs}$ at $318 \mathrm{~K}$ are shown in Figure S3. We found that the adsorption capacities of cartap raised with the adsorption time increasing. When the initial concentration of cartap was set at $4.0 \mathrm{mmol} / \mathrm{L}$, the adsorption equilibrium of cartap $(15 \mathrm{~mL})$ on $50 \mathrm{mg} \mathrm{Fe}_{3} \mathrm{O}_{4} @ \mathrm{mSiO}_{2} @ \mathrm{NIPs}$ could be achieved in $15 \mathrm{~min}$ at $318 \mathrm{~K}$. However, it took more time for $\mathrm{Fe}_{3} \mathrm{O}_{4} @ \mathrm{mSiO}_{2} @ \mathrm{MIPs}$ to attain adsorption equilibrium than $\mathrm{Fe}_{3} \mathrm{O}_{4} @ \mathrm{mSiO}_{2} @ \mathrm{NIPs}$, which might be ascribed to the specific molecular recognition behavior on customized binding sites and stereo-cavity of $\mathrm{Fe}_{3} \mathrm{O}_{4} @ \mathrm{mSiO}_{2} @ \mathrm{MIPs}_{\text {, }}$ while there was physical adsorption onto randomly distributed functional groups on the surface of $\mathrm{Fe}_{3} \mathrm{O}_{4} @ \mathrm{mSiO}_{2} @ \mathrm{NIPs}$. The adsorption equilibrium time of adsorption of cartap on $\mathrm{Fe}_{3} \mathrm{O}_{4} @ \mathrm{mSiO} 2 @ \mathrm{MIPs}$ was $30 \mathrm{~min}$, which means that $30 \mathrm{~min}$ could be regarded as the longest extraction time. For non-surface imprinted polymer, achieving adsorption equilibrium generally needs $12-24 \mathrm{~h} \mathrm{[43].} \mathrm{Therefore,} \mathrm{the}$ binding sites of surface of microspheres provided by surface imprinting technology led to faster mass transfer for binding kinetics. 


\subsection{Evaluation of Selectivity for Recognition}

Molecular recognition ability of $\mathrm{Fe}_{3} \mathrm{O}_{4} @ \mathrm{mSiO}_{2} @ \mathrm{MIPs}$ mainly depends on the binding between $\mathrm{Fe}_{3} \mathrm{O}_{4} @ \mathrm{mSiO}_{2} @ \mathrm{MIPs}$ and adsorbed molecules, and the binding ability is related to similarity between template and adsorbed molecules in functional groups, size and stereo structure [37]. Obviously, the adsorption capacities of five analogues including cartap, nereistoxin, bensultap, bisultap and monosultap (Figure 1) on $\mathrm{Fe}_{3} \mathrm{O}_{4} @ \mathrm{mSiO}_{2} @ \mathrm{NIPs}$ had no significant difference (Figure 5) because of non-specific adsorption. However, the adsorption capacities of five analogues on $\mathrm{Fe}_{3} \mathrm{O}_{4} @ \mathrm{mSiO}_{2} @ \mathrm{MIPs}$ were distinct from one and another and were much higher than those on $\mathrm{Fe}_{3} \mathrm{O}_{4} @ \mathrm{mSiO}_{2} @ \mathrm{NIPs}$.

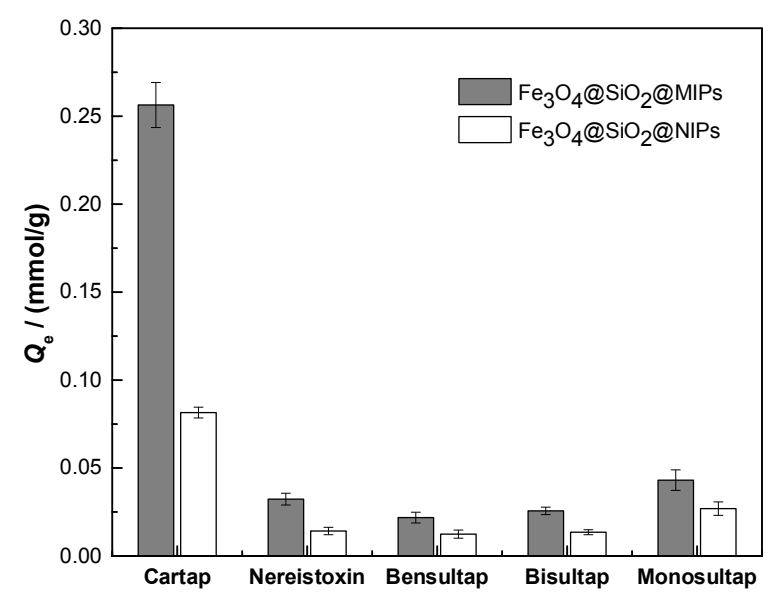

Figure 5. Adsorption capacities of cartap in the presence of its analogues (nereistoxin, bensultap, bisultap, monosultap) in mixture solution with the initial concentrations of $4.0 \mathrm{mmol} / \mathrm{L}$ for each one on $\mathrm{Fe}_{3} \mathrm{O}_{4} @ \mathrm{mSiO}_{2} @ \mathrm{MIPs}$ and $\mathrm{Fe}_{3} \mathrm{O}_{4} @ \mathrm{mSiO}_{2} @ \mathrm{NIPs}$ at $298 \mathrm{~K}$.

As shown in Figure 5, the imprinting factor $\alpha$ calculated for cartap on $\mathrm{Fe}_{3} \mathrm{O}_{4} @ \mathrm{mSiO}_{2} @ \mathrm{MIPs}$ was 3.1, which was much higher than those of $\alpha$ for nereistoxin (2.3), bensultap (1.8), bisultap (1.9) and monosultap (1.6) on $\mathrm{Fe}_{3} \mathrm{O}_{4} @ \mathrm{mSiO}_{2} @ \mathrm{MIPs}$. The results demonstrated that $\mathrm{Fe}_{3} \mathrm{O}_{4} @ \mathrm{mSiO}_{2} @ \mathrm{MIPs}$ had specific adsorption to cartap and implied the success of imprinting process. When the initial concentration was set at $4.0 \mathrm{mmol} / \mathrm{L}$ for each one in mixed solution, the separation factors were calculated as $\beta_{\text {cartap } / \text { nereistoxin }}=7.9, \beta_{\text {cartap } / \text { bensultap }}=11.8, \beta_{\text {cartap } / \text { bisultap }}=10.0$, $\beta_{\text {cartap } / \text { monosultap }}=5.9$, the reason for which was that the specific sites were complementary in size, shape, and spatial distribution of cartap in $\mathrm{Fe}_{3} \mathrm{O}_{4} @ \mathrm{mSiO}_{2} @ \mathrm{MIPs}$. Despite the same moiety of $\mathrm{N}, \mathrm{N}$-dimethyl-dithiolan-amine for five selected analogues, the adsorption capacity of cartap on $\mathrm{Fe}_{3} \mathrm{O}_{4} @ \mathrm{mSiO}_{2} @ \mathrm{MIPs}$ was higher than its analogues.

Four selected analogues had the same central skeleton of $\mathrm{N}, \mathrm{N}$-dimethyl-dithiolan-amine as cartap, but bensultap, bisultap, and monosultap had two sulfonic groups, respectively, and bensultap had another two hydrophobic benzene rings (Figure 1). The lower adsorption capacities for nereistoxin, bensultap, bisultap and monosultap were probably due to non-specific imprinted sites for compounds with different molecular size and stereochemistry [35]. For bensultap, the hydrophobic effect of the benzene rings probably kept it from getting into the binding cavities, and consequently, the binding capacity was weakened. Besides, for bisultap and monosultap, the superhydrophilicity and steric effect of the sulfonic group induced lower adsorption capacity. These results revealed that the imprinting effect of $\mathrm{Fe}_{3} \mathrm{O}_{4} @ \mathrm{mSiO}_{2} @ \mathrm{MIPs}$ could be significant for selective extraction of cartap from the real complicated matrix. Therefore, the properties of $\mathrm{Fe}_{3} \mathrm{O}_{4} @ \mathrm{mSiO}_{2} @ M I P s$ were better than those traditional non-specific sorbents. 


\subsection{Reusability of $\mathrm{Fe}_{3} \mathrm{O}_{4} @ m \mathrm{miO}_{2} @ M I P s$}

The preliminary experimental results demonstrated that methanol-acetic acid $(9 / 1, v / v)$ could attenuate the non-covalent interactions between target analytes and $\mathrm{Fe}_{3} \mathrm{O}_{4} @ \mathrm{mSiO}_{2} @ \mathrm{MIPs}$, so that it was regarded as the optimal desorption solvent to remove templates to regenerate $\mathrm{Fe}_{3} \mathrm{O}_{4} @ \mathrm{mSiO}_{2} @ \mathrm{MIPs}$. The reusability of $\mathrm{Fe}_{3} \mathrm{O}_{4} @ \mathrm{mSiO}_{2} @ \mathrm{MIPs}$ was researched by monitoring the adsorption efficiency of ten batch samples to extend its operational life span for lowering cost. After ten successive adsorption-desorption rounds, the adsorption efficiency was still as high as $95.2 \%$ of the original one (Figure S4), which demonstrates that $\mathrm{Fe}_{3} \mathrm{O}_{4} @ \mathrm{mSiO}_{2} @ \mathrm{MIPs}$ is relatively stable and could be reused ten times with almost no effect on its adsorption efficiency.

\subsection{Selective Enrichment of Cartap from Spiked Tea Beverages}

In this study, we applied a concise and rapid sample pretreatment process of solid phase extracting cartap from tea solution by $\mathrm{Fe}_{3} \mathrm{O}_{4} @ \mathrm{mSiO}_{2} @ \mathrm{MIPs}$ without cartridge packing. After absorbing the analytes in a vial, $\mathrm{Fe}_{3} \mathrm{O}_{4} @ \mathrm{mSiO}_{2} @ \mathrm{MIPs} / \mathrm{Fe}_{3} \mathrm{O}_{4} @ \mathrm{mSiO}_{2} @ \mathrm{NIPs}$ were gathered by an external magnet, and then washed with acetonitrile and then with methanol-acetic acid $(9 / 1, v / v)$ to release analytes [44].

Taking the recovery of cartap and handling time into account, we set the solid-to-liquid ratio of $\mathrm{Fe}_{3} \mathrm{O}_{4} @ \mathrm{mSiO}_{2} @ \mathrm{MIPs} / \mathrm{Fe}_{3} \mathrm{O}_{4} @ \mathrm{mSiO}_{2} @ \mathrm{NIPs}$ to tea solution at 10:3 (mg:mL) and extraction time at 30 min based on the adsorption experiment. The total recoveries of cartap from tea solution after solid phase extraction were confirmed using HPLC. In general, the $\mathrm{Fe}_{3} \mathrm{O}_{4} @ \mathrm{mSiO}_{2} @ \mathrm{MIPs}$ extraction realized almost absolute recovery $(>95 \%)$ of cartap from tea solution while approximately half of the cartap was lost after being treated by $\mathrm{Fe}_{3} \mathrm{O}_{4} @ \mathrm{mSiO}_{2} @ \mathrm{NIPs}$ (data not shown). Moreover, the recovery of cartap from the tea solution decreased with the increase in cartap concentration after being absorbed by both $\mathrm{Fe}_{3} \mathrm{O}_{4} @ \mathrm{mSiO}_{2} @ \mathrm{MIPs}$ and $\mathrm{Fe}_{3} \mathrm{O}_{4} @ \mathrm{mSiO}_{2} @ \mathrm{NIPs}$. This could be result from the adsorption saturation and the decreased equilibrium rate of the polymers.

\subsection{Colorimetric and $U V$-Vis Spectroscopic Determination of Cartap}

Due to the selectivity and effectivity of $\mathrm{Fe}_{3} \mathrm{O}_{4} @ \mathrm{mSiO}_{2} @ \mathrm{MIPs}$ for recognizing and separating cartap from tea beverages, there is no need to take further measurements to ensure the selectivity for the colorimetric determination. After adding cartap standard solutions into the freshly synthesized AgNP colloidal solutions, the changes of the solution's color were recorded (Figure 6A). It illustrated that the color changed from yellow to brown with cartap concentrations raising from 0.01 to $5 \mathrm{mg} / \mathrm{L}$, and then turned to light purple at $10 \mathrm{mg} / \mathrm{L}$. The purple color of the solution diminished and came to be light gray when cartap concentration reached $40 \mathrm{mg} / \mathrm{L}$ due to the intensive aggregation of AgNPs. Hence, we could roughly mensurate the concentrations of cartap $\geq 5 \mathrm{mg} / \mathrm{L}$ by the naked eye based on the colors of the solutions. Nevertheless, when the concentration of cartap was $\leq 1 \mathrm{mg} / \mathrm{L}$, there was no observable variation in color. To enhance the sensitivity of this colorimetric sensor, UV-vis spectra was scanned as showing in Figure 6C. The absorbance intensity at $392 \mathrm{~nm}$ decreased with the concentration of cartap raising and red shift of the spectra was observed at the same time. The plot of the absorbance of cartap with different concentrations at $392 \mathrm{~nm}$ versus the concentration is shown in Figure 6E. The linear regression model could not be testified to correlate the absorbance with cartap concentrations at the range of $0-30 \mathrm{mg} / \mathrm{L}$. Anyway, an intense linear relationship $\left(R^{2}=0.9994\right)$ was determined at the cartap concentrations changing from 0.1 to $5 \mathrm{mg} / \mathrm{L}$, revealing the practicability of using UV-vis spectral colorimetric methods to quantitate cartap of concentrations from 0.1 to $5 \mathrm{mg} / \mathrm{L}$. Fortunately, this value could satisfy the maximum residue limit proposed by the Ministry of Agriculture of China for cartap in teas.

The corresponding tests of using $\mathrm{Fe}_{3} \mathrm{O}_{4} @ \mathrm{mSiO}_{2} @ \mathrm{MIPs}$ to pretreat samples prior to colorimetric sensor determination of cartap in spiked bottled green tea beverages were also conducted. The results shown in Figure 6B,D are consistent with the results of cartap standard solutions quite well, and the 
extraction recovery rate of $98.3-101.6 \%$ was identified by HPLC, implying the practicability of using AgNP-colorimetric sensors for the measurement of cartap residue in tea beverages.

Compared with AgNP colorimetric method after $\mathrm{Fe}_{3} \mathrm{O}_{4} @ \mathrm{mSiO}_{2} @ \mathrm{MIPs}$ pretreatment, the corresponding samples had been analyzed by HPLC at the same time, and the detection results by the two methods were extremely close to each other, and we found that there were no significant differences between the proposed method and traditional HPLC method (Table 1), so the colorimetric analysis method based on $\mathrm{AgNP}$ sensor with $\mathrm{Fe}_{3} \mathrm{O}_{4} @ \mathrm{mSiO}_{2} @ \mathrm{MIPs}$ as recognition elements could be used to detect the cartap in tea products or bottled tea beverages.

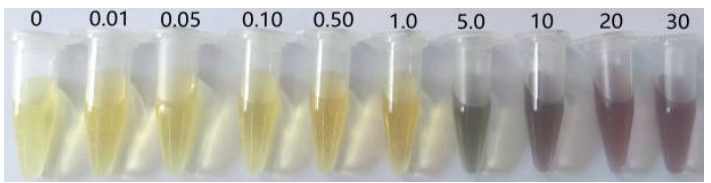

(A)

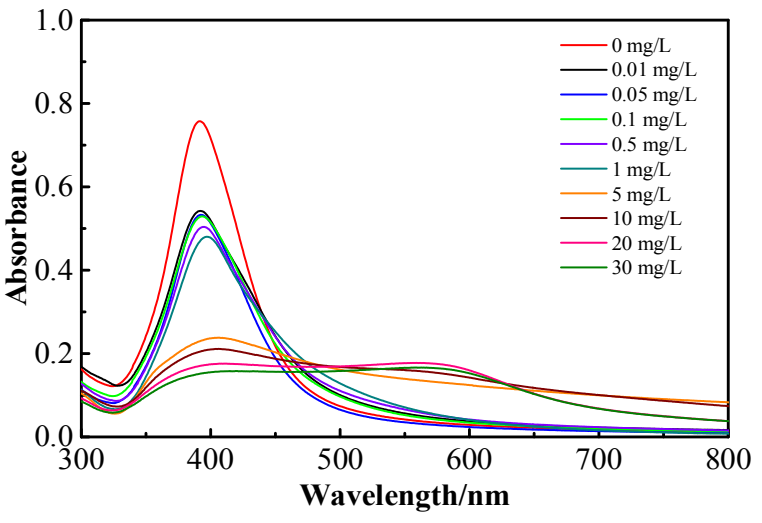

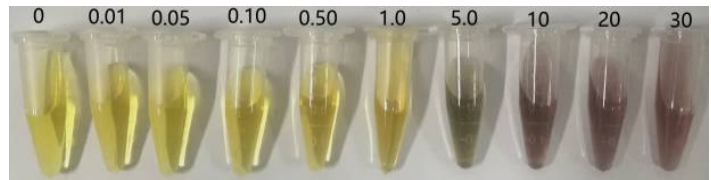

(B)

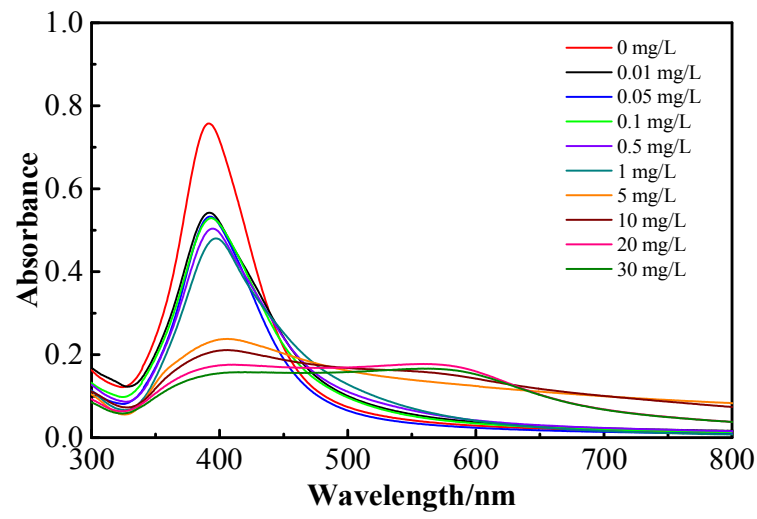

(D)

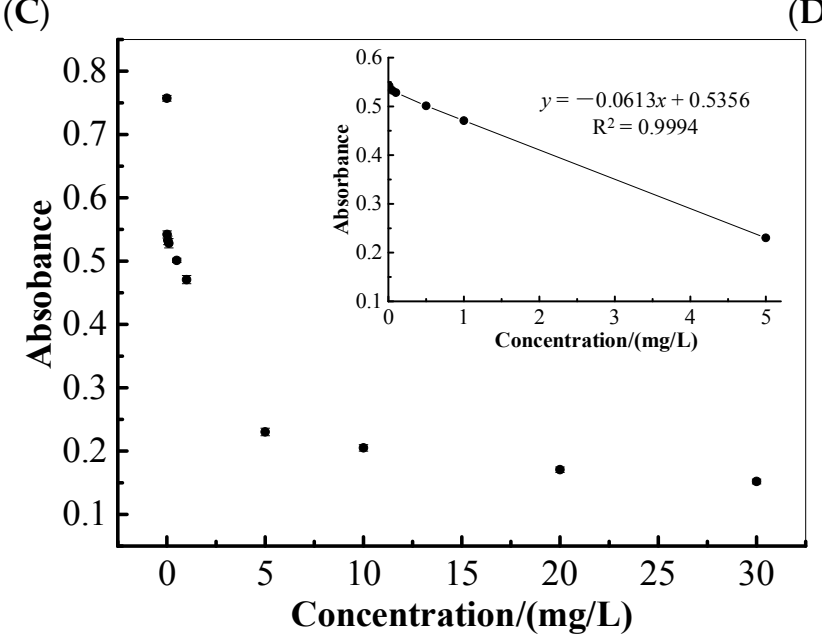

(E)

Figure 6. Representative photographic image of colorimetric sensing with (A) different concentrations $(\mathrm{mg} / \mathrm{L})$ of cartap standard solutions and with (B) $\mathrm{Fe}_{3} \mathrm{O}_{4} @ \mathrm{mSiO}_{2} @ \mathrm{MIPs}$ extracts of bottled green tea beverage spiked with different concentrations $(\mathrm{mg} / \mathrm{L})$ of cartap; average UV-vis absorption spectra of AgNPs (C) in the presence of different concentrations of cartap and (D) in the presence of $\mathrm{Fe}_{3} \mathrm{O}_{4} @ \mathrm{mSiO}_{2} @ \mathrm{MIPs}$ extracts of bottled green tea beverage spiked with different concentrations of cartap; (E) plot of the average absorption values at $392 \mathrm{~nm}$ versus different concentrations of cartap standard solutions $(n=3)$. 
Table 1. AgNP colorimetric detection after $\mathrm{Fe}_{3} \mathrm{O}_{4} @ \mathrm{mSiO}_{2} @ \mathrm{MIPs}-$ pretreatment and HPLC analysis of cartap in cartap-spiked green tea, black tea, white tea, yellow tea, dark tea, oolong tea, bottled green tea, and bottled iced black tea.

\begin{tabular}{|c|c|c|}
\hline Samples * & $\begin{array}{l}\text { AgNP Colorimetric Detection after } \\
\mathrm{Fe}_{3} \mathrm{O}_{4} @ \mathrm{mSiO}_{2} @ \mathrm{MIPs}-\text { Pretreatment }\end{array}$ & HPLC Analysis \\
\hline Green tea $(\mathrm{mg} / \mathrm{kg})$ & $10.112 \pm 0.202^{\mathrm{a}}$ & $10.084 \pm 0.307^{\mathrm{a}}$ \\
\hline Black tea $(\mathrm{mg} / \mathrm{kg})$ & $9.798 \pm 0.219^{a}$ & $9.831 \pm 0.196^{\mathrm{a}}$ \\
\hline White tea $(\mathrm{mg} / \mathrm{kg})$ & $9.965 \pm 0.199^{\mathrm{a}}$ & $10.022 \pm 0.287^{\mathrm{a}}$ \\
\hline Yellow tea (mg/kg) & $9.767 \pm 0.235^{b}$ & $9.779 \pm 0.109^{b}$ \\
\hline Dark tea $(\mathrm{mg} / \mathrm{kg})$ & $10.033 \pm 0.201^{\mathrm{a}}$ & $9.974 \pm 0.214^{\mathrm{a}}$ \\
\hline Oolong tea $(\mathrm{mg} / \mathrm{kg})$ & $10.042 \pm 0.318^{b}$ & $10.013 \pm 0.226^{b}$ \\
\hline Bottled green tea $(\mathrm{mg} / \mathrm{L})$ & $4.027 \pm 0.082^{\mathrm{a}}$ & $4.008 \pm 0.105^{\mathrm{a}}$ \\
\hline Bottled iced black tea $(\mathrm{mg} / \mathrm{L})$ & $3.985 \pm 0.095^{\mathrm{a}}$ & $4.015 \pm 0.083^{\mathrm{a}}$ \\
\hline
\end{tabular}

${ }^{*}$ Each one gram of green tea, black tea, white tea, yellow tea, dark tea, oolong tea was spiked with $10 \mu \mathrm{L}$ of cartap $(1 \mathrm{mg} / \mathrm{mL})$ before extracted with water, respectively; bottled green tea and bottled iced black tea were spiked with cartap till to $4 \mathrm{mg} / \mathrm{L}$. The concentration of cartap was detected by UV-vis spectrometer with the AgNPs as colorimetric sensors. The results were shown on average value $\pm \mathrm{SD}(n=3) .{ }^{\text {a }}$ Significant (two-tailed) at $p \leq 0.05$ level. ${ }^{\mathrm{b}}$ Significant (two-tailed) at $p \leq 0.01$ level.

\section{Materials and Methods}

\subsection{Chemicals and Reagents}

Sodium acetate, $\mathrm{FeCl}_{3} \cdot 6 \mathrm{H}_{2} \mathrm{O}$, polyethylene glycol 6000 (PEG 6000), cetyltrimethyl ammonium bromide (CTAB), tetraethyl orthosilicate (TEOS), acetonitrile, ethanol, acetic acid, acetone and HPLC grade methanol were purchased from Sinopharm Chemical Reagent Co., Ltd. (Shanghai, China). Acrylamide (AM), acrylic acid (AA), methylacrylic acid (MAA), 4-vinylpyridine (4-VP), ethylene glycol dimethacrylate (EGDMA), and 3-(trimethoxysily) propyl methacrylate (MPS) were acquired from Shanghai Macklin Biochemical Co, Ltd. (Shanghai, China). 2,2'-azobis-(isobutyronitrile) (AIBN) was provided by Chinasun Specialty Products co, Ltd. (Jiangsu, China). Cartap with purities over 98\% was purchased from RAM.M Reagent Company, China. Nereistoxin and bensultap with purities over 99\% were obtained from Alfa Chemistry, New York, NY, USA. Both bisultap and monosultap with purities over 99\% were from Crescent Chemical Company, Islandia, NY, USA. Triple distilled water (deionized water) newly collected from a glass distillator (Yarong, Shanghai, China) was used to prepare solutions. Other reagents were of analytical grade and obtained from Sinopharm Chemical Reagent Co., Ltd. (Shanghai, China). Six tea samples (green, black, white, yellow, dark and oolong teas), bottled green tea beverage, and bottled iced black tea beverage were purchased from a local supermarket.

\subsection{Apparatus and Conditions}

FT-IR spectra $\left(4000-400 \mathrm{~cm}^{-1}\right)$ of various particles were obtained from a Nicolet 6700 FT-IR spectrometer (Thermo Nicolet Co., Waltham, MA, USA). The morphology of microspheres was observed on a TEM (Tecnai G2 F20, FEI, Hillsboro, OR, USA). The magnetic property was identified using VSM (Squid-VSM, Quantum Design, San Diego, CA, USA) at room temperature. HPLC analysis was performed on a Purkinje L600 HPLC system (Beijing, China) equipped with a Pgrandsil-STC- $C_{18}$ column ( $250 \mathrm{~mm} \times 4.6 \mathrm{~mm}, 5 \mu \mathrm{m}$, Bonna-Agela, Wilmington, DE, USA) and a UV spectrum detector. With methanol- water $(v / v=20: 80)$ mixture containing $0.17 \%$ acetic acid as the mobile phase, the chromatogram was acquired at $238 \mathrm{~nm}$ with the rate of flow $0.5 \mathrm{~mL} / \mathrm{min}$ and the column temperature $25{ }^{\circ} \mathrm{C}$. UV-vis spectra were scanned on an UV2800 UV-vis spectrophotometry (Sunny Hengping Scientific Instrument Co, Ltd., Shanghai, China).

\subsection{Preparation of $\mathrm{Fe}_{3} \mathrm{O}_{4} @ m \mathrm{SiO}_{2} @ \mathrm{MIPs}$}

$\mathrm{Fe}_{3} \mathrm{O}_{4} @ \mathrm{mSiO}_{2} @ \mathrm{MIPs}$ with cartap as template were synthesized by a surface-imprinted polymerization method using $\mathrm{Fe}_{3} \mathrm{O}_{4}$ nanoparticles as support according to our previous work [35] 
with minor modifications as showing in Figure 2. Firstly, magnetic $\mathrm{Fe}_{3} \mathrm{O}_{4}$ nanoparticles, $\mathrm{Fe}_{3} \mathrm{O}_{4} @ \mathrm{mSiO}_{2}$ microspheres, and vinyl-modified $\mathrm{Fe}_{3} \mathrm{O}_{4} @ \mathrm{mSiO}_{2}$ microspheres were prepared in turn according to our previously published method $[35,37]$.

Then, $0.25 \mathrm{mmol}$ cartap and $1.0 \mathrm{mmol}$ MAA were dissolved in $6.0 \mathrm{~mL}$ anhydrous acetonitrile, purged with $\mathrm{N}_{2}$, then immediately stored in refrigerator at $4{ }^{\circ} \mathrm{C}$ for $12 \mathrm{~h}$ to gain preassembled solution. Then, $50.0 \mathrm{mg}$ vinyl-modified $\mathrm{Fe}_{3} \mathrm{O}_{4} @ \mathrm{mSiO}_{2}, 4.0$ mmol EGDMA and $20.0 \mathrm{mg}$ AIBN were dissolved in $15.0 \mathrm{~mL}$ acetonitrile and added into aforementioned preassembled solution, purged with $\mathrm{N}_{2}$ on ice, then immediately allowed to react at $60^{\circ} \mathrm{C}$ for $24 \mathrm{~h}$ under continuous stirring [37]. After polymerization, ending $\mathrm{Fe}_{3} \mathrm{O}_{4} @ \mathrm{mSiO}_{2} @ \mathrm{MIPs}$ were gathered magnetically, eluted with acetonitrile until the supernatant was transparent, and then rinsed with methanol-acetic acid $(9 / 1, v / v)$ to remove the template completely, which affirmed with a UV-vis spectrometer at $238 \mathrm{~nm}$ ( $\lambda_{\max }$ of cartap) [18]. In the end, the $\mathrm{Fe}_{3} \mathrm{O}_{4} @ \mathrm{mSiO}_{2} @ \mathrm{MIPs}$ were rinsed with methanol to neutralize $\mathrm{pH}$ and vacuum dried overnight at $50{ }^{\circ} \mathrm{C}$. As a control, the same procedures were applied for the synthetization of $\mathrm{Fe}_{3} \mathrm{O}_{4} @ \mathrm{mSiO}_{2} @ \mathrm{NIPs}$ in the absences of template.

\subsection{Adsorption Experiments}

For adsorption equilibrium experiments, $10.0 \mathrm{mg} \mathrm{Fe} \mathrm{O}_{4} @ \mathrm{mSiO}_{2} @ \mathrm{MIPs}$ (or $\mathrm{Fe}_{3} \mathrm{O}_{4} @ \mathrm{mSiO}_{2} @ \mathrm{NIPs}$ ) were suspended in a series of vials containing $3.0 \mathrm{~mL}$ cartap aqueous solutions with starting concentrations ranging from 0.1 to $25.0 \mathrm{mmol} / \mathrm{L}$, respectively. The vials were shaken under $200 \mathrm{rpm}$ for $3 \mathrm{~h}$ at $298 \mathrm{~K}, 308 \mathrm{~K}$, and $318 \mathrm{~K}$, respectively, and the equilibrium concentrations of cartap were analyzed by HPLC. The equilibrium adsorption capacity $Q_{e}(\mathrm{mmol} / \mathrm{g})$ was calculated by the following equation:

$$
Q_{\mathrm{e}}=\left(c_{0}-c_{\mathrm{e}}\right) V / m
$$

where $c_{0}(\mathrm{mmol} / \mathrm{L})$ and $c_{\mathrm{e}}(\mathrm{mmol} / \mathrm{L})$ are the initial concentration and the equilibrium concentration of cartap, respectively. $V(\mathrm{~L})$ is the volume of cartap solution, while $\mathrm{m}$ is the mass of $\mathrm{Fe}_{3} \mathrm{O}_{4} @ \mathrm{mSiO}_{2} @ \mathrm{MIPs}$ or $\mathrm{Fe}_{3} \mathrm{O}_{4} @ \mathrm{mSiO}_{2} @ \mathrm{NIPs}(\mathrm{g})$.

For adsorption kinetic experiments, 50.0 mg Fe $\mathrm{O}_{4} @ \mathrm{mSiO}_{2} @ \mathrm{MIPs}$ (or $\mathrm{Fe}_{3} \mathrm{O}_{4} @ \mathrm{mSiO}_{2} @ \mathrm{NIPs}$ ) were suspended in a vial containing $15.0 \mathrm{~mL}$ cartap water solution $(4.0 \mathrm{mmol} / \mathrm{L})$. The vial was then continually shaken under $200 \mathrm{rpm}$ at $298 \mathrm{~K}$, and the concentrations of cartap in the supernatant at some intervals $(5,10,20,30,40,50,60,90$, and $120 \mathrm{~min})$ were analyzed by HPLC, and then the adsorption capacity $Q_{\mathrm{t}}(\mathrm{mmol} / \mathrm{g})$ at different contact times $\mathrm{t}(\mathrm{min})$ was calculated as:

$$
Q_{\mathrm{t}}=\left(c_{0}-c_{\mathrm{t}}\right) V / m
$$

where $c_{t}(\mathrm{mmol} / \mathrm{L})$ is the concentration of cartap at different contact times.

Furthermore, adsorptive selectivity was executed using cartap in the presence of its four analogues including nereistoxin, bensultap, bisultap and monosultap (Figure 1) as standard mixed solutions with the initial concentrations of $4.0 \mathrm{mmol} / \mathrm{L}$ for each one. The imprinting factor $\alpha$ [45] was used to quantify the specific recognition of the $\mathrm{Fe}_{3} \mathrm{O}_{4} @ \mathrm{mSiO}_{2} @ \mathrm{MIPs}: \alpha=$

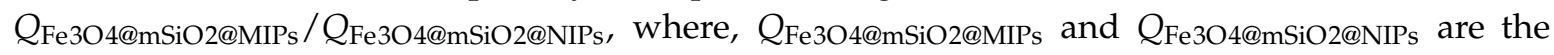
amount of cartap absorbed onto $\mathrm{Fe}_{3} \mathrm{O}_{4} @ \mathrm{mSiO}_{2} @ \mathrm{MIPs}$ and $\mathrm{Fe}_{3} \mathrm{O}_{4} @ \mathrm{mSiO}_{2} @ \mathrm{NIPs}$, respectively. The separation factor $\beta$ [45] was used to evaluate the selective recognition of $\mathrm{Fe}_{3} \mathrm{O}_{4} @ \mathrm{mSiO}_{2} @ \mathrm{MIPs}$ : $\beta=Q_{\text {template }} / Q_{\text {non-template }}$, where $Q_{\text {template }}$ and $Q_{\text {non-template }}$ were the adsorption amount of target molecules and control molecules on $\mathrm{Fe}_{3} \mathrm{O}_{4} @ \mathrm{mSiO}_{2} @ \mathrm{MIPs}$, respectively.

\subsection{Regeneration and Reused Experiments}

$\mathrm{Fe}_{3} \mathrm{O}_{4} @ \mathrm{mSiO}_{2} @ \mathrm{MIPs}$ loaded with cartap from cartap reference solution were collected by a magnet, rinsed with acetonitrile to eliminate the nonspecific adsorption, and then eluted with methanol-acetic acid $(9 / 1, v / v)(1.0 \mathrm{~mL})$ for $1 \mathrm{~h}$ to reach complete cartap desorption. In addition, the $\mathrm{Fe}_{3} \mathrm{O}_{4} @ \mathrm{mSiO}_{2} @ \mathrm{MIPs}$ were washed with methanol to neutral $\mathrm{pH}$, washed with distilled water for 
3 times, and vacuum dried overnight at $50{ }^{\circ} \mathrm{C}$ to regenerate the $\mathrm{Fe}_{3} \mathrm{O}_{4} @ \mathrm{mSiO}_{2} @ \mathrm{MIPs}$ [46]. Then the regenerated $\mathrm{Fe}_{3} \mathrm{O}_{4} @ \mathrm{mSiO}_{2} @ \mathrm{MIPs}$ could be reused to identify reusability.

\subsection{Selective Recognition of Cartap from Tea Beverages by $\mathrm{Fe}_{3} \mathrm{O}_{4} @ m \mathrm{miO}_{2} @ M I P s$}

After being oven-dried for $24 \mathrm{~h}$ at $50^{\circ} \mathrm{C}$, various tea products were ground to 40 -mesh size. The ground samples were re-dried for $8 \mathrm{~h}$ at $50{ }^{\circ} \mathrm{C}$. All six types of tea products and two tea beverages were firstly determined to be free of cartap by HPLC (with LOD of $1.0 \times 10^{-4} \mathrm{mg} / \mathrm{L}$ ) before use. Thus, $1.000 \mathrm{~g}$ tea products spiked with $1 \mathrm{mg} / \mathrm{mL}$ cartap $(10 \mu \mathrm{L})$ were suspended in $25 \mathrm{~mL}$ deionized water of $90{ }^{\circ} \mathrm{C}$. The suspensions were incubated at $90{ }^{\circ} \mathrm{C}$ for more $20 \mathrm{~min}$ before filtrating through $0.45 \mu \mathrm{m}$ filter membrane to save the filtrates for analysis.

In addition, $3 \mathrm{~mL}$ of bottled tea beverages were spiked with different amounts of cartap (i.e., 0 , $0.01,0.05,0.1,0.5,1.0,5.0,10,20$, and $30 \mathrm{mg} / \mathrm{L}$ ), respectively, and then were used to analyze after filtrating through $0.45 \mu \mathrm{m}$ filter membrane.

After that, $\mathrm{Fe}_{3} \mathrm{O}_{4} @ \mathrm{mSiO}_{2} @ \mathrm{MIPs}(10.0 \mathrm{mg})$ were suspended in the above spiked tea solution samples $(3.0 \mathrm{~mL})$. After shaking for $180 \mathrm{~min}$ under $200 \mathrm{rpm}, \mathrm{Fe}_{3} \mathrm{O}_{4} @ \mathrm{mSiO}_{2} @ \mathrm{MIPs}$ were gathered by a magnet, and then rinsed with acetonitrile and methanol-acetic acid $(9 / 1, v / v)(1.0 \mathrm{~mL})$ in turn at $20^{\circ} \mathrm{C}$ to enrich cartap. The eluate was dried with $\mathrm{N}_{2}$, and the residue was dissolved in water and analyzed by HPLC and colorimetric/UV-vis spectroscopic methods.

\subsection{Colorimetric, UV-Vis Spectroscopic and HPLC Determination of Cartap}

AgNPs were synthesized by a simple chemical reduction method. In short, $4.0 \mathrm{~mL}$ of silver nitrate aqueous solution $(0.5 \mathrm{mmol} / \mathrm{L})$ was dropwisely added into $10.0 \mathrm{~mL}$ of freshly prepared sodium borohydride solution $(2.0 \mathrm{mmol} / \mathrm{L})$ under vigorous stirring at $300 \mathrm{rpm}$ for $20 \mathrm{~min}$ at room temperature until the color of the solution turned to yellow [18]. The newly prepared AgNPs were applied to the following experiments right away (within $2 \mathrm{~h}$ ).

The standard stock solutions of cartap at various concentrations (i.e., $0,0.01,0.05,0.1,0.5,1.0,5.0$, 10,20 , and $30 \mathrm{mg} / \mathrm{L}$ ) were prepared by dissolving cartap in deionized water. Typically, $100 \mu \mathrm{L}$ of cartap water solution was added into $400 \mu \mathrm{L}$ of newly synthesized AgNP solution. After gently shaking the mixtures for $10 \mathrm{~min}$ at room temperature, the color changes were observed by naked eyes and also the UV-vis absorption spectra $(200-800 \mathrm{~nm})$ were scanned and recorded [18]. The same processes were also applied for the aforementioned tea solution samples spiked with cartap, which were extracted with $\mathrm{Fe}_{3} \mathrm{O}_{4} @ \mathrm{mSiO}_{2} @ \mathrm{MIPs}$.

The UV-vis absorption spectra of different concentrations of cartap standard solutions and spiked tea solutions extracted with $\mathrm{Fe}_{3} \mathrm{O}_{4} @ \mathrm{mSiO}_{2} @ \mathrm{MIPs}$ from three trials were averaged. The colorimetric detection of cartap in aqueous solution was operated at room temperature. The average absorbance values of all the concentrations or selected concentrations (i.e., $0.01,0.1,0.05,1.0$, and $5.0 \mathrm{mg} / \mathrm{L}$ ) at $392 \mathrm{~nm}$ were plotted.

\subsection{Statistical Analyses}

All statistical analyses were performed using SPSS Statistics (v. 20, IBM, Armonk, NY, USA). Differences between the proposed method and traditional HPLC method were analyzed using one-way analysis of variance (ANOVA).

\section{Conclusions}

In summary, we have successfully established an AgNP colorimetric method with $\mathrm{Fe}_{3} \mathrm{O}_{4} @ \mathrm{mSiO}_{2} @ \mathrm{MIPs}$ as recognition elements to pretreat samples for measurement of cartap from tea beverages. The prepared $\mathrm{Fe}_{3} \mathrm{O}_{4} @ \mathrm{mSiO}_{2} @$ MIPs can effectively solidly extract and separate cartap in tea beverages, while AgNP colorimetry is able to determinate cartap. AgNP colorimetric sensor after $\mathrm{Fe}_{3} \mathrm{O}_{4} @ \mathrm{mSiO}_{2} @ \mathrm{MIPs}$ pretreatment is a rapid high-throughput method to easily identify high concentration of cartap by unaided eyes and is a quantificational mean to detect low concentration 
of cartap using a UV-vis spectrometer. In conclusion, this method exhibits great potential for rapid (the detection time with sample pretreatment $<60 \mathrm{~min}$ ) and accurate measurement of cartap in tea beverages demanded by the food supervision bureau and the food industry.

Supplementary Materials: The following are available online at http:/ /www.mdpi.com/1420-3049/23/6/1443/ s1, Figure S1: The FT-IR spectra of (a) $\mathrm{Fe}_{3} \mathrm{O}_{4}$, (b) $\mathrm{Fe}_{3} \mathrm{O}_{4} @ \mathrm{CTAB} / \mathrm{SiO}_{2}$, (c) vinyl modified $\mathrm{Fe}_{3} \mathrm{O}_{4} @ \mathrm{mSiO}_{2}$ and (d) $\mathrm{Fe}_{3} \mathrm{O}_{4} @ \mathrm{mSiO}_{2} @ \mathrm{MIPs}$, Figure S2: Adsorption isotherms of cartap on (A) $\mathrm{Fe}_{3} \mathrm{O}_{4} @ \mathrm{mSiO}_{2} @ \mathrm{MIPs}$ and on (B) $\mathrm{Fe}_{3} \mathrm{O}_{4} @ \mathrm{mSiO}_{2} @ \mathrm{NIPs}$, Figure S3: Adsorption kinetics curve of $4.0 \mathrm{mmol} / \mathrm{L}$ cartap on $\mathrm{Fe}_{3} \mathrm{O}_{4} @ \mathrm{mSiO}_{2} @ \mathrm{MIPs}$ and $\mathrm{Fe}_{3} \mathrm{O}_{4} @ \mathrm{mSiO}_{2} @ \mathrm{NIPs}$ at $318 \mathrm{~K}$, Figure S4: Reusability of $\mathrm{Fe}_{3} \mathrm{O}_{4} @ \mathrm{mSiO}_{2} @ \mathrm{MIPs}$, and Table S1: Adsorption isotherm constants for the Langmuir and Freundlich equations using adsorption data of cartap on $\mathrm{Fe}_{3} \mathrm{O}_{4} @ \mathrm{mSiO}_{2} @ \mathrm{MIPs}$ and $\mathrm{Fe}_{3} \mathrm{O}_{4} @ \mathrm{mSiO}_{2} @ \mathrm{NIPs}$.

Author Contributions: M.W., H.D., Y.H., Y.G. and L.X. conceived and designed the experiments; M.W., H.D., Y.F. and L.X. performed the experiments; M.W. and Y.G. analyzed the data; M.W., H.D., Y.F., Y.G. and L.X. wrote the paper.

Funding: This research was funded by the National Natural Science Foundation of China (31670563), the Natural Science Foundation of Hunan Province, China (2018JJ2671), and the Technology Foundation for Selected Overseas Chinese Scholar of Ministry of Human Resources and Social Security of China (2015-192, 2016-176).

Acknowledgments: The Authors thank that this work was supported by the National Natural Science Foundation of China (31670563), the Natural Science Foundation of Hunan Province, China (2018JJ2671), and the Technology Foundation for Selected Overseas Chinese Scholar of Ministry of Human Resources and Social Security of China (2015-192, 2016-176). All authors appreciate the editors and the anonymous reviewers for their constructive comments and critical evaluation.

Conflicts of Interest: The authors declare no conflict of interest.

\section{References}

1. Liao, J.W.; Kang, J.J.; Jeng, C.R.; Chang, S.K.; Kuo, M.J.; Wang, S.C.; Liu, M.R.S.; Pang, V.F. Cartap-induced cytotoxicity in mouse $\mathrm{C}_{2} \mathrm{C}_{12}$ myoblast cell line and the roles of calcium ion and oxidative stress on the toxic effects. Toxicology 2006, 219, 73-84. [CrossRef] [PubMed]

2. Berg, H. Pesticide use in rice and rice-fish farms in the Mekong Delta, Vietnam. Crop Protect. 2001, 20, 897-905. [CrossRef]

3. Liu, W.; Zhang, D.; Tang, Y.; Wang, Y.; Yan, F.; Li, Z.; Wang, J.; Zhou, H.S. Highly sensitive and selective colorimetric detection of cartap residue in agricultural products. Talanta 2012, 101, 382-387. [CrossRef] [PubMed]

4. Ministry of Agriculture of People's Republic of China. National Food Safety Standard: Maximum Residue Limits for Pesticides in Food; Ministry of Agriculture of People's Republic of China: Beijing, China, 2016; GB 2763-2016; p. 26.

5. Wang, Z.; Wu, L.; Shen, B.; Jiang, Z. Highly sensitive and selective cartap nanosensor based on luminescence resonance energy transfer between NaYF4:Yb,Ho nanocrystals and gold nanoparticles. Talanta 2013, 114, 124-130. [CrossRef] [PubMed]

6. Yang, T.; Zhou, R.; Jiang, D.; Fu, H.; Su, R.; Liu, Y.; Su, H. Rapid detection of pesticide residues in Chinese herbal medicines by Fourier transform infrared spectroscopy coupled with partial least squares regression. J. Spectrosc. 2016, 2016, 9492030. [CrossRef]

7. Bhatia, J.; Sharma, J.D. Thin-layer chromatographic detection of carbosulfan by 4-aminoantipyrine reagent. J. Planar Chromatogr. Mod. TLC 2011, 24, 545-546. [CrossRef]

8. Wu, G.; Yu, H.; Bao, X.; Chen, H.; Ye, Q. Determination of cartap residues in tea by GC/micro-ECD. Chin. J. Chromatogr. 2007, 25, 288-289. (In Chinese)

9. Vivek, C.; Veeraiah, K.; Padmavathi, P.; Rao, H.D.; Bramhachari, P.V. Acute toxicity and residue analysis of cartap hydrochloride pesticide: Toxicological implications on the fingerlings of fresh water fish Labeo rohita. Biocatal. Agric. Biotechnol. 2016, 7, 193-201. [CrossRef]

10. Tian, K.; Ming, C.; Dai, Y.; Ake, K.M.H. Fenton degradation of cartap hydrochloride: Identification of the main intermediates and the degradation pathway. Water Sci. Technol. 2015, 72, 1198-1205. [CrossRef] [PubMed] 
11. Park, Y.; Choe, S.; Lee, H.; Jo, J.; Park, Y.; Kim, E.; Pyo, J.; Jung, J.H. Advanced analytical method of nereistoxin using mixed-mode cationic exchange solid-phase extraction and GC/MS. Forensic Sci. Int. 2015, 252, 143-149. [CrossRef] [PubMed]

12. Chowdhury, M.A.Z.; Fakhruddin, A.N.M.; Islam, M.N.; Moniruzzaman, M.; Gan, S.H.; Alam, M.K. Detection of the residues of nineteen pesticides in fresh vegetable samples using gas chromatography-mass spectrometry. Food Control 2013, 34, 457-465. [CrossRef]

13. Namera, A.; Watanabe, T.; Yashiki, M.; Kojima, T.; Urabe, T. Simple and sensitive analysis of nereistoxin and its metabolites in human serum using headspace solid-phase microextraction and gas chromatography mass spectrometry. J. Chromatogr. Sci. 1999, 37, 77-82. [CrossRef] [PubMed]

14. Takahashi, K.; Fukuwatari, T.; Shibata, K. Fluorometric determination of pantothenic acid in human urine by isocratic reversed-phase ion-pair high-performance liquid chromatography with post-column derivatization. J. Chromatogr. B 2009, 877, 2168-2172. [CrossRef] [PubMed]

15. Tao, C.J.; Hu, J.Y.; Li, J.Z. Determination of insecticide monosultap residues in tomato and soil by capillary gas chromatography with flame photometric detection. Can. J. Anal. Spectrosc. 2007, 52, 295-304.

16. Saha, K.; Agasti, S.S.; Kim, C.; Li, X.; Rotello, V.M. Gold nanoparticles in chemical and biological sensing. Chem. Rev. 2012, 112, 2739-2779. [CrossRef] [PubMed]

17. Mi, F.-L.; Wu, S.-J.; Zhong, W.-Q.; Huang, C.-Y. Preparation of a silver nanoparticle-based dual-functional sensor using a complexation-reduction method. Phys. Chem. Chem. Phys. 2015, 17, 21243-21253. [CrossRef] [PubMed]

18. Feng, S.; Hu, Y.; Ma, L.; Lu, X. Development of molecularly imprinted polymers-surface-enhanced Raman spectroscopy/colorimetric dual sensor for determination of chlorpyrifos in apple juice. Sens. Actuators B Chem. 2017, 241, 750-757. [CrossRef]

19. Roy, S.M.; Roy, D.R. Levofloxacin capped Ag-nanoparticles: A new highly selective sensor for cations under joint experimental and DFT investigation. Spectrochim. Acta Part A Mol. Biomol. Spectrosc. 2017, 179, $178-187$. [CrossRef]

20. Varun, S.; Daniel, S.C.G. K.; Gorthi, S.S. Rapid sensing of melamine in milk by interference green synthesis of silver nanoparticles. Mater. Sci. Eng. C Mater. Biol. Appl. 2017, 74, 253-258. [CrossRef] [PubMed]

21. Wang, X.; Tao, J.; Chen, X.; Yang, H. An ultrasensitive and selective "off-on" rhodamine-based colorimetric and fluorescent chemodosimeter for the detection of $\mathrm{Cu}^{2+}$. Sens. Actuators B Chem. 2017, 244, 709-716. [CrossRef]

22. Polavarapu, L.; Perez-Juste, J.; Xu, Q.-H.; Liz-Marzan, L.M. Optical sensing of biological, chemical and ionic species through aggregation of plasmonic nanoparticles. J. Mater. Sci. C 2014, 2, 7460-7476. [CrossRef]

23. Zhao, L.; Zhu, J.; Cheng, Y.; Xiong, Z.; Tang, Y.; Guo, L.; Shi, X.; Zhao, J. Chlorotoxin-conjugated multifunctional dendrimers labeled with radionuclide 131I for single photon emission computed tomography imaging and radiotherapy of gliomas. ACS Appl. Mater. Interfaces 2015, 7, 19798-19808. [CrossRef] [PubMed]

24. Patel, G.M.; Rohit, J.V.; Singhal, R.K.; Kailasa, S.K. Recognition of carbendazim fungicide in environmental samples by using 4-aminobenzenethiol functionalized silver nanoparticles as a colorimetric sensor. Sens. Actuators B Chem. 2015, 206, 684-691. [CrossRef]

25. Zhang, R.; Liu, K.; Cui, Y.; Zhang, W.; He, L.; Guo, S.; Chen, Y.; Li, Q.X.; Liu, S.; Wang, B. Development of a monoclonal antibody-based ELISA for the detection of the novel insecticide cyantraniliprole. RSC Adv. 2015, 5, 35874-35881. [CrossRef]

26. Duan, Y.; Wang, L.; Gao, Z.; Wang, H.; Zhang, H.; Li, H. An aptamer-based effective method for highly sensitive detection of chloramphenicol residues in animal-sourced food using real-time fluorescent quantitative PCR. Talanta 2017, 165, 671-676. [CrossRef] [PubMed]

27. Gao, D.; Wang, D.-D.; Zhang, Q.; Yang, F.-Q.; Xia, Z.-N.; Zhang, Q.-H.; Yuan, C.-S. In vivo selective capture and rapid identification of luteolin and its metabolites in rat livers by molecularly imprinted solid-phase microextraction. J. Agric. Food Chem. 2017, 65, 1158-1166. [CrossRef] [PubMed]

28. Xie, X.; Chen, L.; Pan, X.; Wang, S. Synthesis of magnetic molecularly imprinted polymers by reversible addition fragmentation chain transfer strategy and its application in the Sudan dyes residue analysis. J. Chromatogr. A 2015, 1405, 32-39. [CrossRef] [PubMed]

29. Wang, A.; Lu, H.; Xu, S. Preparation of Magnetic Hollow Molecularly Imprinted Polymers for Detection of Triazines in Food Samples. J. Agric. Food Chem. 2016, 64, 5110-5116. [CrossRef] [PubMed] 
30. Li, J.; Lu, J.; Qiao, X.; Xu, Z. A study on biomimetic immunoassay-capillary electrophoresis method based on molecularly imprinted polymer for determination of trace trichlorfon residue in vegetables. Food Chem. 2017, 221, 1285-1290. [CrossRef] [PubMed]

31. Kittlaus, S.; Lipinski, J.; Speer, K. New approaches for determination of glyphosate and aminomethylphosphonic acid from different tea samples-prospects and limits of cleanup with molecularly imprinted polymer and titanium dioxide. J. AOAC Int. 2009, 92, 703-714. [PubMed]

32. Miao, S.S.; Wu, M.S.; Zuo, H.G.; Jiang, C.; Jin, S.F.; Lu, Y.C.; Yang, H. Core-shell magnetic molecularly imprinted polymers as sorbent for sulfonylurea herbicide residues. J. Agric. Food Chem. 2015, 63, 3634-3645. [CrossRef] [PubMed]

33. Yan, L.; Yin, Y.; Lv, P.; Zhang, Z.; Wang, J.; Long, F. Synthesis and application of novel 3D magnetic chlorogenic acid imprinted polymers based on a graphene-carbon nanotube composite. J. Agric. Food Chem. 2016, 64, 3091-3100. [CrossRef] [PubMed]

34. Yan, H.; Cheng, X.; Sun, N. Synthesis of multi-core-shell magnetic molecularly imprinted microspheres for rapid recognition of dicofol in tea. J. Agric. Food Chem. 2013, 61, 2896-2901. [CrossRef] [PubMed]

35. Xie, L.; Guo, J.; Zhang, Y.; Hu, Y.; You, Q.; Shi, S. Novel molecular imprinted polymers over magnetic mesoporous silica microspheres for selective and efficient determination of protocatechuic acid in Syzygium aromaticum. Food Chem. 2015, 178, 18-25. [CrossRef] [PubMed]

36. Hu, X.; Xie, L.; Guo, J.; Li, H.; Jiang, X.; Zhang, Y.; Shi, S. Hydrophilic gallic acid-imprinted polymers over magnetic mesoporous silica microspheres with excellent molecular recognition ability in aqueous fruit juices. Food Chem. 2015, 179, 206-212. [CrossRef] [PubMed]

37. Xie, L.; Guo, J.; Zhang, Y.; Shi, S. Efficient determination of protocatechuic acid in fruit juices by selective and rapid magnetic molecular imprinted solid phase extraction coupled with HPLC. J. Agric. Food Chem. 2014, 62, 8221-8228. [CrossRef] [PubMed]

38. Feng, Z.; Lu, Y.; Zhao, Y.; Ye, H. Fast extraction and detection of 4-methylimidazole in soy sauce using magnetic molecularly imprinted polymer by HPLC. Molecules 2017, 22, 1885. [CrossRef] [PubMed]

39. Katz, A.; Davis, M.E. Molecular imprinting of bulk, microporous silica. Nature 2000, 403, 286. [CrossRef] [PubMed]

40. Zhang, Y.; Nie, M.; Shi, S.; You, Q.; Guo, J.; Liu, L. Integration of magnetic solid phase fishing and off-line two-dimensional high-performance liquid chromatography-diode array detector-mass spectrometry for screening and identification of human serum albumin binders from Radix Astragali. Food Chem. 2014, 146, 56-64. [CrossRef] [PubMed]

41. Zheng, X.; Xu, T.; Shi, R.; Lu, N.; Zhang, J.; Jiang, C.; Zhang, C.; Zhou, J. Preparation of hollow porous molecularly imprinted polymers for N-nitrosamine adsorption. Mater. Lett. 2018, 211, 21-23. [CrossRef]

42. Li, W.; Zhao, D. Extension of the Stober method to construct mesoporous $\mathrm{SiO}_{2}$ and $\mathrm{TiO}_{2}$ shells for uniform multifunctional core-shell structures. Adv. Mater. 2013, 25, 142-149. [CrossRef] [PubMed]

43. Li, L.; He, X.; Chen, L.; Zhang, Y. Preparation of core-shell magnetic molecularly imprinted polymer nanoparticles for recognition of bovine hemoglobin. Chem. Asian J. 2009, 4, 286-293. [CrossRef] [PubMed]

44. You, Q.; Zhang, Y.; Zhang, Q.; Guo, J.; Huang, W.; Shi, S.; Chen, X. High-capacity thermo-responsive magnetic molecularly imprinted polymers for selective extraction of curcuminoids. J. Chromatogr. A 2014, 1354, 1-8. [CrossRef] [PubMed]

45. Zhu, L.L.; Cao, Y.H.; Cao, G.Q. Preparation and application of core-shell magnetic imprinted nanoparticles for bisphenol A. Chin. J. Anal. Chem. 2013, 41, 1724-1728. [CrossRef]

46. Shen, J.; Chai, W.; Wang, K.; Zhang, F. Efficient removal of anionic radioactive pollutant from water using ordered urea-functionalized mesoporous polymeric nanoparticle. ACS Appl. Mater. Interfaces 2017, 9, 22440-22448. [CrossRef] [PubMed]

Sample Availability: Samples of the compounds are available from the authors. 